PROCEDIA

Studi Kasus dan Intervensi Psikologi ISSN:2302-1462; e-ISSN: 2722-7669

Volume 8(3) 101-111, September 2020

DOI: $10.22219 /$ procedia.v8i3.14308

\title{
Terapi perilaku untuk meningkatkan asertivitas pada anak dengan Gangguan Enuresis
}

Purwo Erina Wahyuriko, Universitas Muhammadiyah Malang, Malang, Indonesia

Korespondonesi:

Purwo Erina Wahyuriko, email: errinanizzay2003@gmail.com

\begin{abstract}
Riwayat artikel Naskah diterima:

$01 / 07 / 2020$
\end{abstract}

Revisi diterima: $18 / 08 / 2020$

Naskah disetujui: 10/09/2020

\begin{abstract}
Abstrak
Enuresis merupakan kegagalan untuk mengontrol keluarnya urin baik yang di sengaja maupun tidak disengaja yang dapat terjadi pada anak. Subjek studi kasus ini anak perempuan berusia lima tahun enam bulan yang mengalami gangguan enuresis. Asesmen yang digunakan adalah wawancara klinis, observasi dan tes psikologi WISC. Subjek mengalami enuresis rata-rata lima kali per minggu disebakan karena tidak asertif. Intervensi yang diberikan menggunakan behaviour therapy dengan tujuan untuk meningkatkan perilaku asertif. Hasil intervensi menunjukkan adanya peningkatan perilaku asertif menurunya frekuensi enuresis.

Kata kunci: Terapi perilaku, role play, konseling, perilaku asertif, enuresis
\end{abstract}

\section{Latar Belakang}

Enuresis merupakan kegagalan untuk mengontrol keluarnya urin baik yang di sengaja maupun tidak disengaja yang dapat terjadi pada anak yang berusia diatas 5 tahun. Frekuensi terjadinya enuresis sebanyak dua kali seminggu dan terjadi kurang lebih tiga bulan tanpa adanya riwayat kasus organik (DSM-V). Enuresis adalah inkontinensia urin dimana seharusnya seorang anak sudah mampu berkemih secara normal namun anak tersebut tidak dapat melakukannya sehingga terjadi pengeluaran urin yang tidak pada tempatnya atau sering dinamakan mengompol. Enuresis terbagi menjadi dua macam yaitu enuresis nocturnaldan enuresis diurnal. Enuresis nocturnal adalah enuresis yang terjadi pada malam hari ketika individu tersebut tertidur sedangkan enuresis diurnal adalah enuresis yang terjadi pada siang hari ketika melakukan aktifitas. Gangguan eliminasi pada anak dapat diobati secara efektif setelah melakukan evaluasi diagnostik yang ditargetkan dan pembentukan indikasi spesifik untuk perawatan. Mengingat tekanan emosional yang disebabkan oleh gangguan fisik dan mental, dan potensi kegigihan kemasa remaja, maka mereka harus dievaluasi dan dirawat pada anak-anak yang terkena dampak sejak usia lima tahun ke depan (Gontard \& Kuwertz-bröking, 2019). 
Penjelasan psikodinamika mengemukakan bahwa enuresis merupakan representasi dari ekspresi kemarahan terhadap orang tua dikarenakan berbagai sebab, misalnya seperti pelatihan buang air kecil dan buang air besar yang keras. Selain itu, mengompol juga merupakan representasi pada respon regresi terhadap kelahiran saudara kandung atau beberapa sumber stres lain dan perubahan dalam kehidupan, seperti mulai bersekolah, mengalami kematian orang tua atau anggota keluarga lain. Para ahli teori belajar menekankan bahwa mengompol paling sering muncul pada anak-anak dengan orang tua yang mencoba melatih mereka sejak dini. Kegagalan pada masa awal dapat menghubungkan kecemasan dengan usaha untuk mengontrol buang air kecil. Kecemasan yang terkondisi justru mendorong dan bukan menghambat buang air kecil (Nevid dkk, 2003).

Beberapa faktor penyebab enuresis lainnya adalah keterlambatan perkembangan (maturation delay), Fakta bahwa kebanyakan anak yang mengalami enuresis sampai menjadi sembuh dengan atau tanpa intervensi mendukung keterlambatan perkembangan. Dari Faktor psikologi, enuresis primer dapat disebabkan oleh adanya faktor stres selama periode perkembangan yaitu antara umur 2-4 tahun. Pemisahan dari keluarga, kematian orang tua, kelahiran saudara kandung, pindah rumah, pertengkaran orang tua dan child abuse merupakan keadaan yang paling sering dianggap sebagai faktor presipitasi enuresis. Enuresis yang disebabkan oleh stres biasanya intermiten dan sementara, sedangkan enuresis yang terus menerus yang menyebabkan toilet training yang kurang adekuat (Lawless \& Mcelderry, 2016).

Awal masuk sekolah merupakan sumber stres terhadap sebagian anak. Lingkungan sekolah yang baru dapat membuat anak merasa tidak nyaman yang disebabkan suasana yang tidak menyenangkan ataupun perlakuan dari orang-orang disekitar. Dalam hal ini diperlukan kemampuan anak untuk beradaptasi dan kemampuan untuk menghindari perbuatan yang tidak menyenangkan dari teman-temannya, salah satunya adalah dengan bersikap asertif. Contohnya, perilaku bullying, umumnya para siswa yang mengalami tindakan bullying adalah siswa yang tingkat asertifitasnya rendah (Soendjojo, 2009). Anak yang mendapatkan intimidasi dari anakanak yang lain secara signifikan mempunyai gejala saluran kemih bagian bawah(Zhao, Velez, Faiena, \& Barone, 2015).

Berdasarkan penjelasan diatas sesuai dengan kondisi subjek yang mengalami enuresis. Subjek memasuki lingkungan yang baru yaitu masuk sekolah, dimana hal ini merupakan hal yang baru bagi subjek, yang dapat menjadi sumber stres tersendiri bagi subjek. Selama beberapa bulan disekolah subjek sering mendapat perlakuan yang tidak menyenangkan dari teman-temannya dan subjek tidak mampu menolak dan mengungkapkan ketidaksukaannya terhadap perlakuan temannya sehingga hal tersebut makin memperkuat sumber stres subjek yang akhirnya direpresentasikan lewat enuresis. Subjek pernah mengadu kepada gurunya namun guru kurang memberi perhatian khusus sehingga subjek semakin berperilaku tidak asertif.

Dampak gangguan enuresis ini juga dirasakan oleh orangtua, berdasarkan penelitian bahwa semakin tinggi frekuensi enuresis maka semakin tinggi tingkat stres orangtua. Selain itu semakin tinggi frekuensi enuresis maka semakin rendah kegiatan sosial, kemampuan disekolah dan kompetensi relasional. Enuresis harus diobati karena termasuk gangguan eliminasi, Apabila tidak diobati sejak dini maka akan berlanjut hingga remaja bahkan dewasa (Roccella dkk, 2019). Dampak lain dari enuresis adalah dapat menyebabkan terjadinya gangguan psikologis seperti rasa percaya diri yang rendah, stres keluarga, dan isolasi sosial.

Dengan atau tidak adanya penanganan, kejadian enuresis cenderung menurun secara signifikan namun banyak ahli yang masih percaya bahwa enuresis harus diobati pada masa kanak-kanak karena saat ini tidak ada cara untuk mengidentifikasi anak-anak mana yang akan tetap enuresis ketika dewasa (Goin, 1998). Kesimpulannya adalah bahwa anak-anak yang diobati akan lebih baik pada masa tindak lanjut daripada anak-anak yang tidak diberi perawatan atau pengobatan. Mereka juga menemukan bahwa prosedur berbasis pembelajaran lebih efektif 
daripada medikasi. Berdasarkan kasus yang telah dijelaskan diatas maka terapi yang tepat untuk mengatasi perilaku subjek yang tidak mampu bersikap asertif adalah terapi perilaku dengan teknik roleplay asertif dengan melibatkan orangtua dan guru melalui teknik konseling.

\section{Metode asesmen}

Metode asesmen mengunakan wawancara klinis, yaitu wawancara yang dilakukan untuk mengumpulkan informasi secara mendalam baik melalui subjek maupun orang-orang disekitarnya untuk mengetahui penyebab dan gejala terjadinya gangguan enuresis pada subjek. Observasi, yaitu untuk mengetahui perilaku dan hubungannya dengan lingkungan sekitarnya yang mendukung terjadinya gangguan enuresis pada subjek, dan tes psikologi WISC untuk mengetahui kapasitas inteligensi dan kemampuan subjek dalam menerima terapi dalam mengatasi gangguannya.

\section{Presentasi kasus}

Subjek merupakan anak perempuan berusia lima tahun 6 bulan yang sedang duduk di bangku taman kanak-kanak. Subjek mempunyai kakek dan ayah serta ibu yang bisu dan tuli, sedangkan nenek dan bibinya tidak bisu dan tuli. Subjek mampu berbicara dengan baik, bisa mendengar dan bercerita seperti anak normal pada umumya dikarenakan diajari oleh nenek dan bibinya. Ayah dan ibu subjek mampu membaca dan menulis dengan baik sebab mereka bersekolah di SLB (Sekolah Luar Biasa) dan waktu di sekolah dulu, ayah subjek juga mengompol hingga usia 10 tahun.

Subjek berkomunikasi dengan kedua orangtuanya menggunakan bahasa isyarat, dan berkomunikasi dengan bibi dan neneknya menggunakan bahasa Indonesia. Subjek merupakan satu-satunya anak dan juga cucu didalam keluarganya. Namun di sekolah subjek cenderung pendiam dan pemalu. Ketika berusia tiga tahun subjek sudah terbiasa minta diantar ke kamar mandi apabila ingin buang air kecil. Subjek mulai mengompol ketika masuk TK (Taman Kanak-kanak) rata-rata satu sampai dua kali perminggu, tetapi sejak empat bulan setelah masuk TK, frekuensi subjek mengompol semakin sering yaitu rata-rata lima kali perminggu.

Awal masuk sekolah subjek tergolong anak yang penurut dan selalu menuruti kemauan teman-temannya. Di lingkungan sekolah, subjek memiliki beberapa teman yang baik namun ada juga teman yang galak. Ada juga yang badannya jauh lebih besar dibandingkan subjek. Teman-temannya sering mengejek subjek karena temannya mengetahui bahwa subjek mempunyai ayah dan ibu serta kakek yang bisu. Subjek pernah mengompol di sekolah namun masih jarang. Subjek sering diejek dan ditertawakan karena sering dijemput oleh ayah dan ibunya yang bisu. subjek sering mendapat perlakuan tidak menyenangkan dari temannya seperti disuruh membawakan sepatunya, diambil kuenya, disuruh bawakan tas atau botol minumnya, dan apabila subjek menolak, subjek akan dimarahi dan bahkan pernah dicubit. Subjek pernah melaporkan hal tersebut kepada gurunya, namun guru mengabaikannya, sehingga membuat Subjek makin tidak berani menolak dan tidak mengungkapkan ketidaknyamannya terhadap perilaku dari teman-temannya. Akibat dari perilaku tersebut, Subjek makin sering mengompol dengan frekuensi lima kali seminggu.

Perubahan hidup dengan memasuki sekolah baru merupakan sumber stres bagi sebagian anak-anak dengan usia masuk sekolah. Ada banyak kemungkinan dilingkungan sekolah baru mendapatkan suasana yang tidak menyenangkan ataupun perlakuan dari orang-orang disekitar yang tidak membuat individu tersebut merasa nyaman. Dalam hal ini diperlukan kemampuan anak untuk beradaptasi dan kemampuan untuk menghindari perbuatan yang tidak menyenangkan dari teman-temannya, salah satu caranya adalah bersikap asertif, misalnya perilaku bullying, umumnya para siswa yang mengalami tindakan bullying adalah siswa yang tingkat asertifitasnya rendah (Soendjojo, 2009). 
Perubahan kehidupan yang dialami subjek dengan memasuki lingkungan baru yaitu sekolahnya merupakan sumber stres tersendiri bagi subjek. selama disekolah subjek mendapatkan perlakuan yang tidak menyenangkan seperti mengganggu dan mengintimidasi subjek. Subjek tidak bisa menolak perbuatan teman-temannya yang selalu mengganggunya sehingga hal tersebut semakin memperkuat sumber stresnya. Dalam hal ini subjek mengalami kesalahan belajar dari lingkungannya, ketika melapor kepada gurunya untuk mendapat pembelaan, subjek diabaikan sehingga subjek tidak melapor lagi dan memilih diam atau tidak asertif. Perilaku manusia merupakan hasil timbal balik yang berkesinambungan antara kognitif, perilaku dan pengaruh lingkungan (Bandura, 1971).

Berdasarkan hasil tes WISC, subjek memiliki kapasitas inteligensi (IQ:115) kategori rata-rata atas dan tidak ditemukan adanya kemunduran fungsi inteligensi dan kemunduran kapasitas intelektual. Subjek memiliki kelebihan terhadap kesadaran akan lingkungan dan kemampuan dalam bidang sosial serta memiliki penilaian yang baik. Subjek mempunyai kelemahan dalam organisasi visual motorik dan kurang bisa menempatkan sesuatu dalam konfigurasi yang lazim. Subjek juga memiliki kekurangan dalam gagasan, pengalaman atau minat yang telah dicapai. Subjek memiliki kelemahan dalam kemampuan belajar verbal yang terakumulasi dan kelemahan dalam hal motivasi, selain itu subjek mengalami kesulitan dalam berhubungan dengan orang lain.

Ketidakmampuan subjek bersikap asertif membuat subjek semakin stres dan direpresentasikan melalui enuresis sebagai bentuk coping. Anak yang mendapatkan intimidasi dari anak yang lain secara signifikan terkait dengan gejala saluran kemih bagian bawah (Zhao, Velez, Faiena, \& Barone, 2015). Psikodinamika mengemukakan bahwa mengompol merupakan representasi pada respon regresi terhadap kelahiran saudara kandung atau beberapa sumber stres lain atau perubahan dalam kehidupan, seperti mulai bersekolah, atau mengalami kematian orang tua atau anggota keluarga lain (Nevid dkk, 2003).

Ada empat kategori yang dikelompokkan dalam perilaku asertif yaitu kemampuan untuk berinisiasi dengan memulai percakapan/menyambung/menghentikan percakapan, berani berkata "tidak", mengajukan suatu pertanyaan dan keinginan, yang terakhir adalah mengekspresikan perasaan suka dan tidak suka. Latihan asertif merupakan latihan ketrampilan sosial yang diberikan kepada individu yang mengalami kecemasan, tidak mampu mempertahankan hak-haknya, terlalu lemah, membiarkan orang lain merongrong dirinya, tidak mampu mengekspresikan amarahnya dengan benar dan cepat tersinggung (Walker, 1996). Sikap tidak asertif yang dimiliki subjek adalah tidak berani berkata "tidak", tidak bisa menyatakan keinginannya dan tidak bisa mengekspresikan perasaan suka dan tidak suka.

Berdasarkan permasalahan diatas, maka perilaku yang perlu diubah atau ditingkatkan adalah perilaku asertifnya. Dengan meningkatkan perilaku asertif, subjek mampu membela diri dan melindungi dirinya dari gangguan sehingga mengurangi tekanan yang dialaminya. Sedangkan terapi yang tepat untuk subjek guna meningkatkan perilaku asertif adalah dengan menggunakan pendekatan terapi perilaku yaitu dengan latihan asertif serta pemberian edukasi dengan orang tua dan guru. Latihan asertif dapat dilakukan dengan menggunakan prosedur permainan peran atau roleplay. Dengan fokus mempraktekan melalui permainan peran yang dapat membantu subjek dalam mengembangkan cara-cara komunikatif pada situasi-situasi sosial sehingga diharapkan mampu mengatasi ketidakmampuannya dalam belajar dan mengungkapkan perasaan-perasaan serta pikiran-pikiran secara lebih terbuka disertai keyakinan bahwa mereka berhak untuk menunjukan reaksi-reaksi terbuka (Corey, 2013).

\section{Diagnosis dan Prognosis}

Berdasarkan uraian kasus yang sebelumnya telah dijelaskan melalui hasi asesmen dan rujukan pada Diagnostic and Statistical Manual of Mental Disorder Fifth Edition (APA, 2013), maka 
dapat ditegakkan diagnosis bahwa subjek memenuhi kriteria diagnostic: enuresis 307.6 (F98.0), dengan gejala subjek berkemih dicelana pada siang hari (mengompol) dengan frekuensi rata-rata lima kali dalam seminggu dan telah berlangsung selama empat bulan.

Subjek memiliki prognosis baik karena adanya motivasi yang kuat untuk melindungi diri sendiri dari bullying teman sekolah. Selain itu, subjek juga sangat ingin berhenti mengompol dan keinginan ini didukung oleh keluarga dan gurunya.

\section{Intervensi}

Intervensi menggunakan teknik roleplay guna melatih kemampuan anak bersikap asertif, edukasi dengan orang tua serta edukasi dengan guru disekolahnya. Latihan asertif merupakan tindakan untuk melatih seseorang mencapai perilaku asertif (Kaplan \& Saddock, 2005). Melalui metode ini subjek akan dilatih dengan teknik bermain peran, subjek didorong untuk melakukan perbuatan yang dikehendaki yaitu mampu memunculkan perilaku asertif seperti bisa menolak dengan berkata tidak dan bisa mengungkapkan keinginannya.

Edukasi dengan orang tua bertujuan untuk memberi wawasan kepada orang tua mengenai dukungan-dukungan yang diperlukan untuk melatih subjek berperilaku asertif. Sedangkan edukasi kepada guru bertujuan untuk memberi wawasan kepada guru untuk mengawasi subjek selama dikelas dan memberi dukungan kepada subjek untuk berperilaku asertif. Alasan menggunakan metode ini adalah agar perilaku yang muncul yaitu kemampuan menolak dan menyampaikan keinginannya itu bisa dimiliki oleh subjek sehingga subjek mampu membela diri dan mencegah subjek dari gangguan teman-temannya.

Dengan meningkatnya kemampuan subjek dalam bersikap asertif khususnya berhadapan dengan teman yang selama ini mengintimidasi dan mengganggu subjek, diharapkan bisa melindungi diri subjek dari gangguan teman-temannya. Selain itu kemampuan subjek bersikap asertif bisa membuat subjek lebih mampu beradaptasi dengan lingkungan dan terlepas dari tekanan yang membuat subjek sering mengompol yang merupakan representasi dari ekspresi ketidaknyamannya.

Intervensi yang diberikan, berupa latihan asertif yang diberikan kepada subjek dengan cara bermain peran atau roleplay, dan juga melakukan edukasi kepada orang tua dan guru di sekolahnya. Setelah dilakukan proses pendekatan terhadap subjek dan orang-orang yang terlibat dengan subjek untuk menjalin rapport dan proses asesmen, berikutnya dilakukan proses intervensi secara sistematis melalui beberapa sesi. Adapun prosedur latihan asertif yang digunakan dalam kasus ini dilaksanakan sebanyak sembilan sesi, antara lain;

Sesi 1: Pengenalan intervensi. Memberikan penjelasan mengenai proses intervensi dan manfaat dari intervensi yang akan dilakukan, seperti menjelaskan penyebab terjadinya gangguan dan cara mengatasinya sehingga subjek dan keluarga mampu dan bersedia mengikuti proses terapi sampai akhir sesi.

Pada sesi pertama ini hubungan terapeutik terjalin dengan baik, meskipun awalnya terapis mengalami kesulitan dalam menjalin komunikasi dengan orang tua karena keterbatasan bahasa, namun ada tante subjek yang bersedia menjadi penerjemah. Hubungan dengan subjek terjalin dengan baik dan terapis bisa menumbuhkan kepercayaan subjek terhadap terapis. Kegiatan pada sesi pertama ini berjalan dengan baik dan lancar serta mendapatkan hasil berupa adanya pemahaman dari apa yang disampaikan terapis, sekaligus adanya kepercayaan dari subjek dan orang terdekat subjek.

Sesi 2: Menentukan perilaku yang akan ditingkatkan. Terapis menggali dan mengidentifikasi perilaku yang diinginkan oleh subjek dan harapan-harapannya serta menentukan perilaku akhir yang diperlukan. Selain itu terapis membantu subjek membedakan perilaku yang dibutuhkan dan yang tidak dibutuhkan dalam rangka menyelesaikan masalahnya. 
Dalam sesi ini terapis memberi penjelasan bahwa perilaku yang akan ditingkatkan pada kasus subjek adalah kemampuan bersikap asertif, yang mana subjek dilatih untuk mengungkapan apa yang dirasakan dihadapan teman-temannya, khususnya teman yang sering mengganggunya. Subjek dilatih untuk menolak dan menyampaikan keinginannya.

Dalam sesi ini subjek dan keluarga mampu memahami dengan baik, apa yang disampaikan oleh terapis dan mengerti dengan bentuk perilaku yang akan dimunculkan. Subjek juga menyatakan keinginan dan harapan-harapannya terhadap perlakuan teman-temannya dengan berhenti menganggu subjek. Subjek dan keluarga juga memahami mengenai penjelasan terapis tentang latihan yang diberikan untuk melatih subjek berperilaku asertif. Disini perubahan tercapai sesuai dengan yang diharapkan.

Sesi 3: Pemberian edukasi kepada guru. Terapis memberikan edukasi kepada guru mengenai hal apa saja yang bisa dilakukan untuk mendukung subjek bersikap asertif. Terapis juga memberikan saran kepada guru untuk lebih memantau suasana kelas khususnya dan teman-temannya yang sering mengganggu subjek. Selain itu terapis memberikan saran-saran untuk membantu subjek agar berani bersikap asertif didepan teman-temannya pada saat subjek tidak dalam pengawasan guru. Terapis juga meminta kerjasama guru untuk mengingatkan subjek, agar segera memberi tahu guru ke kamar mandi jika ada tanda -tanda subjek ingin buang air kecil. Subjek tidak boleh menahan atau takut untuk ke kamar kecil. Dalam sesi ini terapis meminta kerjasama guru untuk terlaksananya proses intervensi.

Pada sesi ini guru memahami dan bersedia bekerjasama untuk membantu mendukung subjek bersikap asertif di depan teman-temannya yang sering mengganggu subjek. Awalnya guru tidak tahu jika ada permasalahan mengenai subjek dan guru sekarang lebih lega sebab akhirnya mengetahui apa yang menyebabkan subjek selalu mengompol dan cara mencegahnya. Guru juga memahami bahwa beberapa perlakuan tidak menyenangkan yang dilakukan oleh teman-teman lebih sering terjadi pada saat guru tidak sedang mengawasi pada saat bermain. Selain mendukung subjek berlatih bersikap asertif dan guru lebih memperhatikan suasana di dalam kelasnya dan menegur serta menasehati apabila ada anak yang mengintimidasi anak lain yang lebih lemah. Guru juga bersedia untuk memantau frekuensi mengompol setiap harinya, serta mengingatkan subjek untuk memberitahu guru apabila subjek ingin buang air kecil sehingga guru membantunya untuk segera ke kamar kecil. Pada sesi ini berjalan dengan baik dan perubahan tercapai sesuai dengan yang diharapkan.

Sesi 4: Pemberian edukasi kepada orang tua. Terapis menjelaskan kepada orangtua mengenai hal-hal apa saja yang harus dilakukan untuk mendukung subjek bersikap asertif didepan teman-temannya. Disini bibi subjek sebagai penerjemah bahasa isyarat. Terapis memberi contoh-contoh secara verbal maupun ekspresi didepan orangtua dan tantenya mengenai bentuk-bentuk dukungan yang bisa diberikan kepada subjek. Terapis mengarahkan orangtua dan tantenya untuk selalu mengingatkan dan mendukung setiap akan berangkat sekolah serta menanyakan keadaannya setiap pulang sekolah. Orangtua dan keluarga diarahkan untuk selalu mendukung subjek bersikap asertif dan memberikan pujian apabila subjek memunculkan perilaku yang diharapkan.

Pada sesi ini orang tua dan bibi subjek memahami apa yang subjek jelaskan dan setuju untuk melakukan yang terapis sarankan. Orangtua sangat mendukung munculnya sikap asertif pada subjek. Orangtua juga mengerti bahwa harus selalu mengingatkan subjek untuk berani membela dirinya dengan mengatakan "tidak mau", "tidak boleh" dan "jangan", dalam menghadapi teman-teman yang sering mengganggunya. Orangtua subjek bersedia untuk memberi dorongan ketika mengantarkan ke sekolah. Orang tua subjek dan bibinya mengerti bahwa harus memberi dorongan kepada subjek untuk bersikap asertif yang harus tetap dipertahankan baik selama di sekolah maupun di rumah. Selain itu orang tua juga memahami untuk memantau seberapa 
sering subjek mengompol di sekolahnya. Pada sesi ini tercapai perubahan sesuai dengan yang diharapkan.

Sesi 5: Latihan roleplay asertif/bermain peran. Pada sesi ini terapis melatih subjek untuk berperilaku asertif dengan cara bermain peran. Latihan bermain peran ini dilakukan dirumah subjek. Disini terapis memberikan umpan balik serta pemberian model perilaku yang lebih baik. Terapis memberi kesempatan kepada subjek untuk menunjukan contoh-contoh perilaku yang mengganggu subjek dan terapis mencontohkan bersikap dan berkata bagaimana terhadap temannya. Kemudian subjek mendapat giliran menirukan apa yang terapis contohkan dan terapis menjadi model seperti teman-teman subjek yang mengganggunya. Disini terapis memberi contoh dengan verbal maupun perilaku dan ekspresi.

Pada sesi ini subjek memahami dengan sangat baik proses latihan bermain peran yang terapis ajarkan. Disini subjek mendemonstrasikan perilaku yang terapis ajarkan, subjek mengatakan "tidak mau" ketika terapis berperan sebagai teman yang menyuruhnya membawakan sepatunya ketika hendak belajar berwudhu. Selain itu, subjek juga mengatakan "tidak boleh" ketika terapis berperan sebagai temannya yang mengambil kue dari tempat bekalnya. Disini subjek juga menirukan ekspresi yang diajarkan oleh terapis. pada sesi ini berjalan dengan cukup lancar dan diperoleh perubahan sesuai dengan harapan.

Sesi 6: Latihan role play asertif. Pada sesi ini terapis mendampingi subjek disekolahnya, terapis kembali memberikan contoh-contoh bagaimana caranya bersikap kepada temannya disekolah khususnya yang paling sering mengganggunya, seperti yang diajarkan sesi sebelumnya. terapis mengulang kembali latihan seperti sebelumnya dan menyuruh subjek mendemontrasikannya didepan terapis sebelum masuk kelingkungan sekolah. Terapis mendorong subjek untuk berani mengatakan "tidak mau" dan "tidak boleh" serta menunjukan ekspresi penolakan apabila ada teman-temannya memerintahkan sesuatu yang subjek tidak sukai. Terapis datang kesekolah subjek untuk mendampingi dan memberikan pujian serta dorongan kepada subjek setelah bisa melakukan perilaku yang dikehendaki, sebagai bentuk penguatan positif.

Dalam sesi ini subjek memahami mengenai apa saja yang harus dilakukan untuk menolak suruhan temannya yang subjek tidak sukai dan bisa menyampaikan keinginanya. subjek mulai berani menolak ketika temannya yang lebih besar darinya akan mengambil kuenya tanpa seijin subjek. subjek mengatakan "tidak boleh" dan menarik kuenya kepangkuannya. Selain itu ketika ada temannya yang menyuruh subjek membawakan botol minumannya, subjek menyuruh temannya untuk membawanya sendiri. Disini subjek masih tampak kaku dan takut-takut menunjukkan sikap asertif untuk pertama kalinya. Subjek menerima pujian dari terapis dan dari orangtuanya, subjek tampak senang. Pada sesi ini terapi berjalan lancar dan perubahan tercapai dengan cukup baik.

Sesi 7: Mengulang role play asertif dan praktik.Pada sesi ini, terapis mendampingi subjek untuk melatih kemampuannya menolak keinginan temannya dan menyampaikan keinginannya, namun terapis mendampinginya dengan memantau dari kejauhan. Terapis memantau aktivitas subjek ketika bermain dengan teman-temannya terutama apabila didatangi oleh teman yang sering mengganggunya. Selain itu terapis juga melihat mengenai tugas yang diberikan kepada subjek untuk mempraktekkan langsung hasil latihan roleplay yang telah diajarkan, tanpa pendampingan langung oleh terapis. disini terapis meminta bantuan guru untuk terlibat dalam setiap sesinya.

Dalam sesi ini subjek tampak mulai menunjukkan sikap asertifnya. Ketika temannya yang paling ditakutinya datang mendekat untuk menyuruhnya pindah tempat duduk, subjek menolak dengan mengatakan tidak mau. Ketika temannya menunjukkan ekspresi marah dan mendekat untuk mencubit, subjek segera bergeser mendekati gurunya dan mengatakan kepada gurunya bahwa subjek tidak mau pindah dari tempat duduk yang disukainya. Subjek mulai 
tampak berani menunjukkan sikap asertifnya, meskipun beberapa kali masih tampak takut dan ragu-ragu. Namun sudah mulai tampak jelas subjek mampu membela diri. Pada sesi ini berjalan lancar dan perubahan tercapai sesuai yang diharapkan.

Sesi 8: Pemberian tugas.Pada sesi ini terapis memberikan tugas kepada subjek untuk berlatih dan mempraktikan perilaku asertifnya tanpa pendampingan terapis. Terapis meminta bantuan guru untuk memantau langsung dari jarak yang tidak terlalu dekat, mengenai aktifitas subjek ketika bermain bersama dengan teman-temannya apakah mampu menyatakan keinginannya dan menolak perlakuan teman-temannya yang tidak menyenangkan kepada subjek. Disini subjek tidak didampingi orangtua dan bibinya, namun informasi mengenai perubahan perilaku subjek diperoleh melalui guru.

Pada sesi ini subjek mampu bersikap asertif dengan mengatakan tidak mau ketika subjek disuruh mengambilkan sepatu oleh teman yang memerintahnya. Ketika ada temannya yang menunjukan sikap tidak suka dengan memelototi subjek maka subjek membalas melotot juga. Saat kejadian itu guru tidak melihatnya dan subjek pun tidak didampingi oleh orang tua. Sehingga subjek telah bersikap asertif tanpa pendamping. Temannya yang sering mengganggunya juga sudah mulai jarang memerintahnya seperti yang sebelumnya. Menurut keterangan subjek juga bahwa hari ini sudah tidak mengompol lagi. Pada sesi ini berjalan dengan baik dan adanya perubahan yang tercapai sesuai dengan harapan.

Sesi 9: Evaluasi dan terminasi. Pada sesi ini terapis memastikan apakah subjek tetap bersikap asertif dengan berani menolak perintah-perintah temannya yang subjek tidak sukai dan mengungkapkan keinginannya. Terapis juga menanyakan perlakuan apa saja yang belakangan teman-temannya lakukan untuk mengganggu subjek dan perilaku apa yang subjek lakukan untuk melindungi dirinya. Selain itu terapis juga menanyakan kepada subjek, guru, orang tua mengenai perubahan perilaku subjek dan juga mengenai frekuensi mengompol subjek. Terapis menanyakan hambatan yang dialami subjek dalam proses melaksanakan terapi, dan memberikan penguatan terhadap usaha yang telah dilakukan subjek selama ini, memberikan saran untuk mengatasi hambatan yang disampaikan. Dalam sesi ini terapis juga menjelaskan kepada subjek dan keluarga bahwa intervensi telah selesai.

Pada sesi ini subjek mengatakan bahwa sekarang telah mampu mengungkapkan keinginan dan penolakannya terhadap teman-temannya yang sering menggaggunya. Guru memberikan informasi bahwa subjek telah mampu meunjukan perilaku asertifnya apabila ada temannya yang mengganggunya baik ketika ada guru maupun ketika sendirian beraktifitas bersama teman-temannya. Selain berani menolak dan menyatakan keinginannya subjek juga mampu mengekspresikan ketidaknyamanannya apabila mendapatkan gangguan. subjek menolak dan mengatakan tidak mau apabila ada temannya yang menyuruhnya dengan intimidasi. Meskipun perasaan takut akan dicubit temannya kadang-kadang masih muncul. Selain itu subjek sekarang lebih bersemangat ke sekolah dan mulai ceria selama di sekolahnya, karena selain subjek telah mampu bersikap asertif, sekarang banyak teman-temannya yang berhenti mengganggunya. Berdasarkan keterangan subjek dan informasi dari guru serta orangtua, diketahui bahwa subjek telah jarang mengompol lagi di sekolahnya. Pada sesi ini subjek dan orangtua mengerti bahwa intervensi telah selesai, Dalam sesi ini berjalan dengan cukup baik dan pada sesi ini perubahan tercapai sesuai dengan yang diharapkan.

\section{Hasil dan Pembahasan}

\section{Hasil}

Hasil yang didapatkan dari kegiatan intervensi, yaitu adanya penurunan frekuensi enuresis subjek. Selain adanya penurunan frekuensi enuresis didapatkan hasil juga bahwa terdapat peningkatan sikap asertif. Subjek mampu bersikap asertif, seperti menolak kemauan 
teman-temannya yang subjek tidak sukai dan mampu mengungkapkan ketidaknyamannya ketika ada teman yang mengganggunya, Selain itu, subjek mampu mengekspresikan perasaan suka atau tidak yang selama ini subjek tidak bisa tunjukkan. Subjek juga mampu menyampaikan keinginannya secara mandiri dihadapan teman-temannya.

Latihan asertif dapat dilakukan dengan menggunakan prosedur permainan peran atau roleplay. Fokusnya adalah mempraktekan melalui permainan peran yang akan membantu subjek dalam mengembangkan cara-cara komunikatif dalam situasi-situasi sosial sehingga diharapkan mampu mengatasi ketidakmampuannya dalam belajar bagaimana mengungkapkan perasaan-perasaan dan pikiran-pikiran secara lebih terbuka disertai keyakinan bahwa mereka berhak untuk menunjukan reaksi-reaksi terbuka itu (Corey, 2013).

Pada tahap awal subjek belum mampu menolak temannya yang suka memerintahnya, belum bisa berkata tidak, namun sudah mampu mengekspresikan ketidaksukaannya terhadap perilaku teman-temannya yang mengganggunya. Ketika ada teman yang akan mengambil kuenya, subjek segera menariknya, ketika dulu subjek diam saja dan menyerahkan kuenya diambil oleh temannya.

Pada intervensi berikutnya berangsur-angsur subjek mampu menunjukkan sikap asertifnya dengan mampu berkata tidak, menolak perintah teman-temannya dengan menolak untuk membawakan botol dan sepatu temannya. Selain itu subjek juga bisa mengungkapkan kemauannya dengan mempersilakan temannya untuk membawa barang-barangnya sendiri dan memilih tempat duduk sendiri. Subjek juga mampu menolak ketika ada temannya yang menyuruhnya pindah dari tempat duduknya. Selain itu subjek telah mampu berusaha menghindar dan berkata jangan ketika ada teman yang akan mencubitnya. Subjek mampu berperilaku asertif tanpa pendampingan terapis dan orang tua meskipun masih mendapatkan pantauan dan dukungan oleh guru dikelasnya.

Dengan munculnya perilaku asertif subjek, maka terdapat adanya penurunan frekuensi mengompol pada subjek yaitu sebelum intervensi subjek mengompol sebanyak lima kali perminggu, kemudian setelah akhir intervensi subjek hanya mengompol sekali seminggu. Sebelum intervensi subjek mengompol setiap hari rata-rata lima kali dalam seminggu, minggu kedua menjadi rata-rata tiga kali perminggu, minggu ketiga menjadi rata-rata dua kali perminggu dan pada minggu keempat rata-rata sekali perminggu. Berdasarkan evaluasi dengan munculnya perilaku asertif subjek, diiringi juga penurunan frekkuensi mengompol dan ketika subjek ingin buang air kecil, subjek berani menyampaikan keinginanya kepada gurunya untuk keluar dari kelas dan pergi ke kamar mandi.

Tiga minggu setelah intervensi (follow up) menunjukan bahwa subjek hanya mengompol sekali dan bahkan subjek tidak lagi mengompol. Subjek tetap mampu bersikap asertif terhadap teman-temannya, terutama terhadap teman yang mengganggunya selama di sekolah. Selain itu, pada hasil follow up menunjukan bahwa subjek hanya mengompol satu kali seminggu di sekolah ketika bermain dengan teman-temannya maupun ketika mengikuti pelajaran.

\section{Pembahasan}

Kemampuan anak bersikap asertif membuat subjek bisa mengungkapkan dan mengekspresikan apa yang diinginkan dan apa yang tidak diinginkan subjek. Perilaku demikian mengurangi tekanan yang dirasakan oleh subjek serta membuat teman-temannya mengetahui bahwa subjek mampu membela haknya. Ketidakmampuan subjek dalam bersikap asertif ketika mendapatkan gangguan dari teman disekolahnya membuat subjek makin tertekan yang direpresentasikan dengan mengompol berlebihan. Hal ini sesuai dengan penelitian bahwa anak yang mendapatkan intimidasi dari anak yang lain secara signifikan terkait dengan gejala saluran kemih bagian bawah anak (Zhao, Velez, Faiena, \& Barone, 2015). 
Subjek mengalami gangguan maupun intimidasi dari teman-teman dilingkungan sekolahnya, subjek sudah pernah berusaha untuk mengadukan kepada gurunya namun gurunya mengabaikannya. Akhirnya subjek mengembangkan sikap tidak asertif yang muncul akibat kesalahan proses belajar dari lingkungannya, seperti tidak menolak dan tidak mengungkapkan ketidaknyamannya terhadap perbuatan teman-temannya. Dalam kondisi tersebut enuresis subjek makin bertambah parah. Latihan asertif dapat diterapkan terutama pada situasi-situasi interpersonal dimana individu kesulitan untuk menerima kenyataan bahwa menyatakan atau menegaskan diri adalah tindakan yang benar (Corey, 2013).

Latihan asertif dapat dilakukan dengan menggunakan prosedur permainan peran atau roleplay. Fokusnya adalah mempraktekan melalui permainan peran yang akan membantu subjek dalam mengembangkan cara-cara komunikatif dalam situasi-situasi sosial sehingga diharapkan mampu mengatasi ketidakmampuannya dalam belajar bagaimana mengungkapkan perasaan-perasaan dan pikiran-pikiran secara lebih terbuka disertai keyakinan bahwa mereka berhak untuk menunjukan reaksi-reaksi terbuka (Corey, 2013).

Proses intervensi yang diberikan bisa berjalan dengan baik dikarenakan ikut melibatkan orangtua dan guru dikelas. Disini orangtua dan bibinya memberikan dukungan penuh untuk terus melatih subjek agar berperilaku asertif baik itu di rumah dan sebelum berangkat sekolah sesuai dengan yang terapis ajarkan. Selain itu guru sangat membantu proses intervensi dengan memberikan dukungan kepada subjek untuk berperilaku asertif apabila ada teman yang mengganggunya. Guru juga sering mengingatkan subjek untuk memberi tahu guru atau meminta ijin untuk ke kamar mandi apabila terasa ingin buang air kecil. Guru juga menjadi lebih waspada terhadap suasana di kelasnya untuk lebih memperhatikan yang lemah dan memberi nasehat kepada yang kuat agar tidak terjadi masalah yang kuat menindas yang lemah.

Intervensi yang digunakan mampu untuk memunculkan perilaku asertif yang diberikan kepada subjek terdiri dari sembilan sesi, dalam semua sesi tersebut memperoleh peruabahan yang diharapkan. Pada kasus ini perilaku asertif perlu ditingkatkan untuk mengatasi tekanan-tekanan yang selama ini didapatkan oleh subjek sehingga mampu mengurangi dampak maladaptif seperti enuresis. Perilaku asertif yang bisa subjek munculkan bisa membuat teman-teman subjek berhenti mengganggu dan bisa membuat klieh lebih percaya diri sehingga menjaga subjek dari ejekan teman maupun sangsi sosial.

\section{Simpulan}

Terapi perilaku dapat meningkatkan perilaku asertif pada anak yang sering mendapatkan perlakuan tidak menyenangkan di sekolah sehingga mengalami gangguan enuresis. Anak yang mampu menunjukan sikap asertif terutama terhadap orang lain yang mengganggunya, mampu menghindarkan diri dari perbuatan yang tidak menyenangkan dari lingkungannya.

\section{Referensi}

Alwisol. (2009). Psikologi kepribadian. Malang: UMM Press

American Psychiatric Association. (2005). Diagnostic and statistical manual of mental disorders (4th ed.) Washington DC. American Psychiatric Association

Corey, Gerald. (2007). Teori dan Praktik Konseling dan Psikoterapi .Bandung: PT. Refika Aditama

Gontard, A. Von, /\& Kuwertz-Bröking E. (2019). The diagnosis and treatment of enuresis and functional daytime urinary incontinence. Deutsches Ärzteblatt Internationa; 116: 279-85 Roccella, M., \& Smirni, D., \& Smirni, P., Precenzano, F., Operto, F. F., Lanzara, V., .. Carotenuto, M. (2019). Parental Stress and Parental Ratings of Behavioral Problems of Enuretic Children. Frontiers in neurology. Volume 10, October 2019.

Lawless, M. R., \& Mcelderry, D. H. (2016). Nocturnal enuresis: Current concepts. 22(12).

Zhao, P. T., Velez, D., Faiena, I., Creenan, E. M., \& Barone, J. G. (2015). Enuresis Bullying has a Potential Role in Pediatric Lower Urinary Tract Symptoms. Journal of Urology, 193(5), 1743-1748. https://doi.org/10.1016/j.juro.2014.08.123 
Sadock, B.J., Sadock, V, A., \& Kaplan, H, I. (2005). Comprehensive text-book of psychiatry (8th Ed.). Philadelphia: Lippicont Williams \& Wilkins.

Sattler, M., Jerome. (2002). Assesment of children, behavioral and clinical application. San Diego State University Suwardi, S, S. (2000). Enuresis pada anak sekolah. Jakarta. Tesis. Universitas Indonesia

Walker, K.E. (1996) The effect of Self-esteem on the Relationship Between Assertiveness and Depression. (Doctoral dissertation, Fuller Theological Seminary). 